\title{
Carbohydrate-degrading bacteria closely associated with Tetraselmis indica: influence on algal growth
}

\author{
Mani Arora ${ }^{1,2}$, Arga Chandrashekar Anil ${ }^{1, *}$, Jane Delany ${ }^{2}$, \\ Nithyalakshmy Rajarajan ${ }^{3}$, Kaveh Emami ${ }^{4}$, Ehsan Mesbahi ${ }^{2}$ \\ ${ }^{1}$ National Institute of Oceanography, Council of Scientific and Industrial Research, Dona Paula, Goa 403004, India \\ ${ }^{2}$ School of Marine Science and Technology, ${ }^{3}$ School of Chemical Engineering and Advanced Materials, \\ and ${ }^{4}$ School of Biology. Devonshire Building, Newcastle University, Newcastle upon Tyne, NE1 7RU, UK
}

\begin{abstract}
In the present study, we examined the interactions between the algal species Tetraselmis indica and strains of bacteria with which it is closely associated. Three bacterial strains were isolated and sequence analysis of the 16S rDNA indicated that the organisms belong to the genera Pseudomonas, Acinetobacter and Ruegeria. Morphologies of the bacterial strains were studied using epifluorescence microscopy and scanning electron microscopy. Reassociation experiments were conducted with axenic cultures inoculated with the 3 bacterial strains in concentrations comparable to natural conditions, and the effect of each bacterial population on the growth of $T$. indica was determined. $T$. indica exhibited differential growth with the various bacterial cultures, and in particular Acinetobacter sp. was observed to promote growth of the algae. These experiments revealed that microbes associated with the alga differentially influence algal growth dynamics. Bacterial presence on the cast-off cell wall products of the alga suggested the likely utilisation of algal cell wall by bacteria. The bacterial strains were tested for carbohydrate metabolism using various sugars and screened for carbohydrase activity. Bacterial strains were found to produce carbohydrases for degradation of polysaccharides generally present in the cell wall of Tetraselmis (glucans, galactans, galactomannans and pectins), whereas no such utilisation was observed for other wall substrates (such as cellulose, arabinoxylan, rhamnogalacturonan). Pseudomonas sp. and Acinetobacter sp. showed carbohydrase activity with glucans, galactans, galactomannans and pectin, whereas Ruegeria sp. showed much less carbohydrase activity and only with pectin. The carbohydrate utilisation studies using artificial substrates suggested the potential utilisation of cast-off algal cell wall products.
\end{abstract}

KEY WORDS: Tetraselmis indica $\cdot$ Aquatic ecosystems $\cdot$ Associated bacteria $\cdot$ Reassociation experiments $\cdot$ Carbohydrate utilisation $\cdot$ Algal growth

\section{INTRODUCTION}

Phytoplankton release considerable amounts of organic components into the extracellular medium, most of which are utilised by bacteria (Williams 1981, Coveney 1982, Cole et al. 1988, Coveney \& Wetzel 1989, Ducklow \& Carlson 1992, Kormas 2005). Consequently, heterotrophic bacteria are often found in close association with algae, which are able to provide a favourable habitat for these bacteria within aquatic ecosystems (Caldwell 1977, Paerl \& Pinckney 1996). The possible role of bacteria in enhancing the growth of algae has been documented (Cid et al. 1992, del Giorgio et al. 1997, Moreno \& Laine 2004, de Kluijver et al. 2010). Lange $(1967,1970,1971)$ proposed that bacteria 
may be a significant source of $\mathrm{CO}_{2}$ for algal growth during periods of carbon limitation.

The taxa of bacteria that can be cultured from samples of phytoplankton are often different from those that can be cultured from water samples (Simidu et al. 1971, Kogure et al. 1981, Cole 1982). Specific bacteria are habitually associated with phytoplankton and are highly adapted for utilisation of extracellular algal products (Bershova et al. 1968, Kuentzel 1969, Bell \& Mitchell 1972, Bell \& Sakshaug 1980, Meffert \& Overbeck 1985, Maurin et al. 1997, Aota \& Nakajima 2001, Huang et al. 2004, Zifeng et al. 2009). Heterotrophic utilisation of algal products can be expected to be a function of both the activity of the heterotrophs and of the suitability of the excreted material (Coveney 1982). In addition to the exudation of organic components (Mague et al. 1980, Bjørnsen 1988, Myklestad et al. 1989, Obernosterer \& Herndl 1995), algal components released through cell lysis (Brussaard et al. 1988) and the cast off theca (Lewin 1958, Gooday 1971, Becker et al. 1991) may be an important carbon source for bacteria.

In the present study, we examined the interactions between an algal species and the strains of bacteria with which it is closely associated under controlled conditions. The alga used for this purpose was Tetraselmis indica (M. Arora et al. unpubl.) collected from a salt pan in Goa, India. During the non-motile phase of this alga, new walls develop and old walls are cast off and accumulate as concentric rings surrounding the cell.

The bacterial strains isolated from Tetraselmis indica were grown in combination with axenic cultures of $T$. indica and the interactions between bacteria and algae were examined. In order to test the hypthesis that bacteria degrade and utilise cast-off algal cell wall products, the bacterial utilisation of carbohydrates was investigated.

\section{MATERIALS AND METHODS}

\section{Isolation of culturable planktonic and epiphytic bacteria}

Tetraselmis indica cultures were maintained in F/2 media (Guillard \& Ryther 1962) without silicates at $25^{\circ} \mathrm{C}$ with a photon flux density of $80 \mu \mathrm{mol}$ photons $\mathrm{m}^{-2} \mathrm{~s}^{-1}$ and a $16 \mathrm{~h}$ light:8 $\mathrm{h}$ dark cycle. For isolation of bacteria, $500 \mathrm{ml}$ of $T$. indica culture (in sterile $\mathrm{F} / 2$ algal culture media) was sonicated using a sonicator (Ultrawave $\mathrm{U} 300 \mathrm{H}$ with ultrasonic power $35 \mathrm{~W}$ and operating frequency $44 \mathrm{KHz}$ ) for $5 \mathrm{~min}$ and filtered through a sterile GF/C (1.2 $\mu \mathrm{m})$ Whatman glass fibre filter. The filtrate was again filtered through a $0.2 \mu \mathrm{m}$ Whatman membrane filter whilst under vacuum. The $0.2 \mu \mathrm{m}$ filters containing bacteria were then washed using $2 \mathrm{ml}$ of sterile seawater and mildly sonicated (for $3 \mathrm{~min}$ ). Serial dilutions $\left(10^{-1}\right.$ to $\left.10^{-6}\right)$ were prepared using sterile seawater. A $0.1 \mathrm{ml}$ aliquot of each dilution was then plated onto marine agar (Difco) and on various selective media in triplicate under aseptic conditions. As controls, $0.1 \mathrm{ml}$ aliquots of $0.2 \mu \mathrm{m}$ filtrate and F/2 media were also plated on marine agar and selective media. Marine agar was chosen as a generalised medium to grow all the culturable bacteria from algal culture. Depending on the source of isolation, any micro- or macroalgae from seawater may contain culturable coliforms, vibrios, as well as other heterotrophic bacteria such as Shewanella, Alteromonas, Planococcus etc. We therefore chose to use:

(1) A-1 medium (Difco) for growth of coliforms including Escherichia coli,

(2) Thiosulfate citrate bile salts sucrose agar (TCBS, Difco) for growth of Vibrio spp.,

(3) Pseudomonas isolation agar (Difco) for growth of pseudomonads,

(4) Sea-water agar (SWA, DSMZ, 246) (Difco) for growth of heterotrophic bacteria.

Marine agar, TCBS, A-1 and SWA plates were incubated at $25^{\circ} \mathrm{C}$ for $24 \mathrm{~h}$ and the plates for selective pseudomonad growth at $37^{\circ} \mathrm{C}$ for $48 \mathrm{~h}$.

\section{Identification and phylogenetic analysis of bacteria}

Three characteristic bacterial morphologies were identified from all the replicates of marine agar plates, representing the diversity of bacteria associated with Tetraselmis indica. Single colony morphology of similar type was observed in each plate of A-1 medium, Pseudomonas isolation agar medium and SWA. Single colonies from each plate were streaked for pure strain isolation. Identification of bacterial strains was performed by $16 \mathrm{~S}$ rDNA sequence analysis. Amplification of the 16S rRNA gene sequences was performed using genomic DNA as the template, extracted using the standard alkaline-lysis protocol from whole bacteria (Birnboim \& Doly 1979). The $16 \mathrm{~S}$ rRNA gene was PCR-amplified for all strains using universal prokaryotic primers: 27F 5'-AGA GTT TGA TCC TGG CTC AG-3' (E. coli 27-47) and 1492R 5'-TACGGT TAC CTT GTT ACG ACT T-3' (E. coli 1492-1514) (Lane 1991). The amplification reactions were carried out using a QIAGEN Fast Cycling PCR Kit and an Eppendorf Mastercycler PCR machine. Dye terminator se- 
quencing, using the same primers as in the amplification step, and an Applied Biosystems 3730xl DNA Analyzer at Newcastle University were used to obtain the nucleotide sequences. 16S rDNA sequences were then compared with those available in the National Centre for Biotechnology Information (NCBI) database using the BLASTN algorithm (Altschul et al. 1990), and the percentage identity was determined. Consensus sequences were aligned using CLUSTALW2 (Hall 1999, Larkin et al. 2007). The TrN+I+G (Tamura-Nei) Model was selected using MEGA v5 (Tamura et al. 2011) and used as a model of nucleotide substitution for the phylogenetic inference of each sequence by the maximum likelihood method. Neighbour joining and maximum parsimony trees were also inferred using MEGA. The sequences obtained were submitted to NCBI GenBank under the accession numbers JF828049, JF828050 and JF828051 for Pseudomonas, Acinetobacter and Ruegeria sp., respectively.

\section{Morphological study of bacteria}

Cultured cells were sampled during the late exponential growth phase. Cells were stained using SYBR Gold stain at a working dilution of $10 \mu \mathrm{lml}^{-1}$ (Molecular Probes, Invitrogen, 1:100 dilution in distilled water) and observed under epifluorescence microscopy. For scanning electron microscopy (SEM), cells were fixed in $2 \%$ glutaraldehyde (TAAB Laboratory Equipment), cacodylate and seawater. Cells were allowed to settle on poly-l-lysine-coated coverslips before placing the coverslips in a holder and dehydrating the cells in an ethanol series (10 min each in $25 \%$, $50 \%$ and $75 \%$ followed by twice for $15 \mathrm{~min}$ in $100 \%$ ). The coverslips were dried in a critical point dryer (BalTec) and subsequently mounted on stubs with a silver DAG and carbon disc (Agar Scientific). Finally, the cells were sputtered with gold (using a Polaron SEM coating unit) and observed using a Stereoscan S40 Scanning Electron Microscope (Cambridge Instruments) at the Electron Microscopy Unit of the School of Biomedical Sciences, Newcastle University.

\section{Growth in axenic culture with different types of bacteria}

\section{Preparation of axenic and xenic cultures of phytoplankton}

Tetraselmis indica cells were washed (5 times) with sterile seawater before and after mild sonication (3 min) to remove closely adhered bacterial cells. Cultures were incubated in carbenicillin $\left(0.02 \mathrm{~g} \mathrm{l}^{-1}\right)$ for $24 \mathrm{~h}$, then were given a sterile wash. Cultures were allowed to recover for $6 \mathrm{~d}$ by incubating in sterile F/2 algal culturing medium (Guillard \& Ryther 1962) at $20^{\circ} \mathrm{C}$ before being incubated in fresh sterile $\mathrm{F} / 2$ medium containing $0.1 \mathrm{~g} \mathrm{l}^{-1}$ cefotaxime for a further $24 \mathrm{~h}$ at $20^{\circ} \mathrm{C}$. Cultures were given 5 repeated sterile washes and transferred to antibiotic-free F/2 medium. The purity of the algal cultures was tested using 3 methods: first, the spread plate method using Zobell marine agar (Himedia); second, by microscopic investigation after fluorochrome staining the cultures using 4',6-diamidino-2-phenyl indole (DAPI) and acridine orange; and third, by flow cytometry using SYBR Gold fluorescent stain (Molecular Probes, Invitrogen) and a BD FACS Aria II flow cytometer. For flow cytometry, samples were run at a rate of $10 \mu \mathrm{min}^{-1}$ on a FACS Aria II flow cytometer (Becton Dickinson) equipped with a $488 \mathrm{~nm}$ excitation laser and a standard filter setup. To create xenic cultures of algae (microalgal cultures containing bacteria), axenic cultures (75 ml each) were inoculated directly at the start of the experiments with a mixed community of the bacteria (presumably culturable as well as non-culturable) present in the original isolate. The mixed community of marine bacteria was obtained from the sonicated culture at the end of the exponential phase by filtration through a sterile GF/C Whatman glass fibre filter (Brussaard et al. 1998). The filtrate was then used as the bacterial inoculum and was added into axenic culture for preparation of xenic cultures of $T$. indica. The mixed bacterial community therefore consisted of a group of bacterial species originally present in the culture and adapted to the specific culture conditions. The concentration of bacteria at the start of the experiments was between 0.45 and $0.6 \times 10^{6}$ cells $\mathrm{ml}^{-1}$. A control was prepared using the axenic culture which received $5 \mathrm{ml}$ of the $0.2 \mu \mathrm{m}$ filtrate containing no bacteria.

\section{Estimation of bacterial and algal population by counting}

For the estimation of bacterial biomass, all cultures were subjected to mild sonication and filtered through $1.2 \mu \mathrm{m}$ GF/C filters before the optical density at $590 \mathrm{~nm}$ was measured. Bacterial cell counts were obtained using epifluorescence microscopy and the acridine orange direct count method (Hobbie et al. 1977). Cell counts were also 
calculated by staining the cells with SYBR Gold (Molecular Probes, Invitrogen) and using flow cytometry.

To study the effect of each bacterial type on the phytoplankton population in terms of cell numbers, growth dynamics of axenic culture and xenic culture were studied under standard culture conditions. A single colony from each bacterial plate was suspended in $1 \mathrm{ml}$ of sterile seawater which was serially diluted to give a range of $10^{-1}$ to $10^{-6}$ cells ml ${ }^{-1}$. Each strain of bacteria was prepared at a density of $3.2 \times$ $10^{6}$ cells $\mathrm{ml}^{-1}$. Then $5 \mathrm{ml}$ of each bacterial inoculum was added to $75 \mathrm{ml}$ of axenic culture to give a final bacterial concentration of $0.4 \times 10^{6} \mathrm{cells} \mathrm{ml}^{-1}$, a comparable concentration to those of xenic cultures. Total cell counts were performed using microscopy and phytoplankton growth was considered as being in the stationary phase when the cell counts did not differ significantly for 3 successive days. Algal growth during exponential, stationary and senescence phases was studied using cell counts calculated with a haemocytometer. For both xenic and axenic cultures, specific growth rates $\left(K^{\prime}\right)$ for Days 10 to 18 (exponential phase) of the experiment were calculated according to Levasseur et al. (1993) using the following formula and were averaged:

$$
K^{\prime}=\ln \left(N_{2} / N_{1}\right) /\left(t_{2}-t_{1}\right)
$$

where $N_{1}$ and $N_{2}$ are the cell counts at times (d) $t_{1}$ and $t_{2}$, respectively.

A comparison of dead cell counts of axenic culture in combination with various bacteria was performed using SYTOX Green stain (Molecular Probes, Invitrogen) and a BD FACS Aria II flow cytometer. Samples were run at a rate of $10 \mu \mathrm{min}^{-1}$ on a FACS Aria II flow cytometer (Becton Dickinson) equipped with a $488 \mathrm{~nm}$ excitation laser and a standard filter setup.

\section{Carbohydrate utilisation (mono- and disaccharide)}

Biochemical assays were performed on all 3 bacterial strains isolated to test their ability to metabolise the various carbohydrates (see Table 1) resulting in the formation of an acid and the production of $\mathrm{CO}_{2}$. The medium used for these assays contained peptone $(10 \mathrm{~g})$, beef extract $(1 \mathrm{~g}), \mathrm{NaCl}(5 \mathrm{~g})$ and phenol red $(0.018 \mathrm{~g})$. The above-mentioned components were dissolved in $500 \mathrm{ml}$ distilled water and the volume made up to $1 \mathrm{l}$. This broth was sterilised in an autoclave at $120^{\circ} \mathrm{C}$ for $15 \mathrm{~min}$. Solutions of each sugar (10\%) were prepared by adding $2 \mathrm{~g}$ to $20 \mathrm{ml}$ distilled water and autoclaving below $100^{\circ} \mathrm{C}$. Then $4 \mathrm{ml}$ of phenol red broth and $1 \mathrm{ml}$ of each sugar solution were dispensed into tubes containing Durham gascollecting tubes for gas detection. A sample of each of the assigned bacteria was aseptically inoculated into each of the phenol red broth tubes, using a loop.

Following incubation, carbohydrates that had been metabolised produced an acidic waste product causing the phenol red to turn yellow, indicating a positive reaction. In certain cases, acid production was accompanied by the evolution of gas $\left(\mathrm{CO}_{2}\right)$ which was visible as a bubble in the inverted tube.

\section{Evaluation of the biodegradability of carbohydrate substrates (polysaccharides)}

Eight types of biodegradable substrates (see Table 2) were used in this study; azo-galactan, azocarob galactomannan, AZ-rhamnogalacturonan, azoCM-cellulose, red pullulan, wheat arabinoxylan, $\beta$-glucan (Megazyme) and citrus pectin (Sigma) were added to the culturing media SWA at a concentration of $2.5 \mathrm{~g} \mathrm{l}^{-1}$. Pure colonies of each bacterium were streaked onto media in triplicate and incubated at $37^{\circ} \mathrm{C}$ for $48 \mathrm{~h}$. Cleavage of the chromogenic substrates by bacteria produced a halo-like precipitation zone around the bacteria, indicating positive activity. Non-chromogenic substrates were stained using 1\% congo red for $15 \mathrm{~min}$ and a similar halo-like precipitation was observed following destaining with $1 \mathrm{M}$ $\mathrm{NaCl}$ in cases of positive activity.

\section{RESULTS}

\section{Isolation, identification and phylogenetic analysis of bacteria}

Three media, A-1, Pseudomonas isolation agar and SWA, demonstrated that 3 morphologically different bacterial colonies were present. Similar colonies were observed on marine agar. TCBS agar did not yield any bacterial growth, indicating the absence of vibrios in culture. Sequence analysis of $16 \mathrm{~S}$ rDNA from duplicates indicated that the organisms isolated from Tetraselmis indica belonged to the Acinetobacter, Ruegeria and Pseudomonas genera. The Pseudomonas sp. showed maximum sequence similarity to $P$. stutzerii $(98 \%)$, the Acinetobacter sp. to A. haemolyticus (98\%) and the Ruegeria sp. to $R$. atlantica (97\%) (Fig. 1 and see Supplement 1 at www.int-res.com/articles/suppl/b015p061_ supp.pdf). 

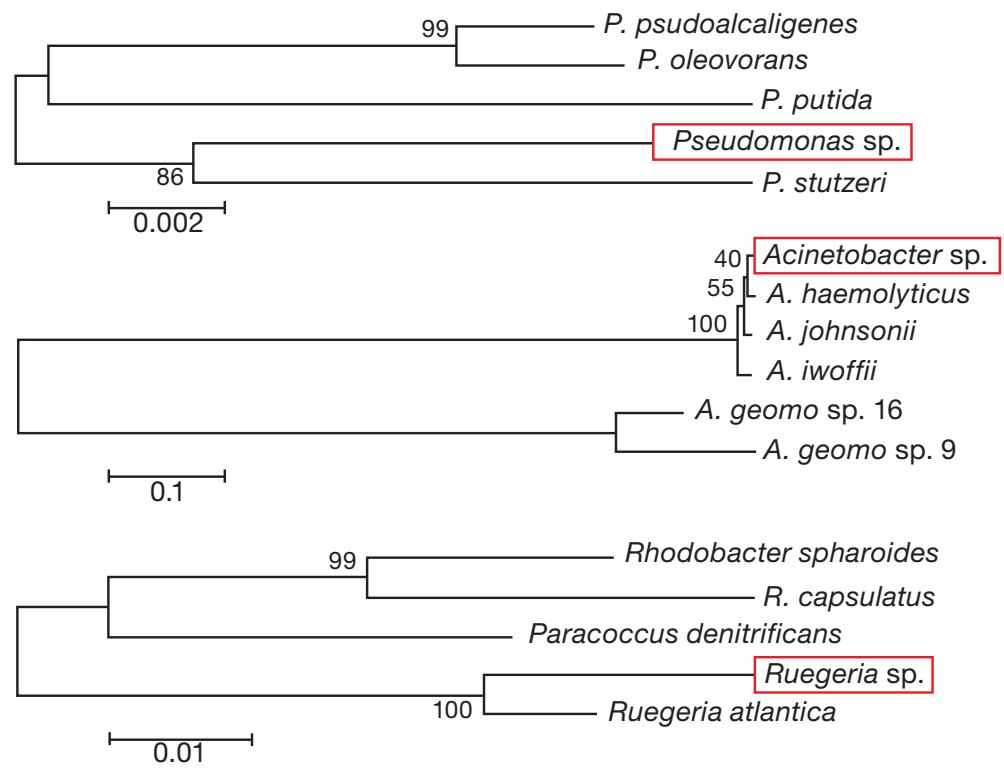

Fig. 1. Acinetobacter sp., Pseudomonas sp. and Ruegeria sp. Phylogeny of the 3 bacterial strains based on 16S rDNA sequences, showing their position in relation to the closest species of their respective genera. Original strains sequenced in this study are highlighted using red squares. The phylogenetic tree shown was inferred by the maximum likelihood method based on the Tamura \& Nei (1993) model of DNA substitutions

\section{Morphologies with epifluorescence microscopy and SEM}

The 3 isolates were observed by epifluorescence microscopy and SEM. All morphological features observed were typical of the corresponding genera. Morphologies as observed under epifluorescence microscopy correlated well with those viewed by SEM. Acinetobacter sp. was seen to be present in pairs (Fig. 2A,B) as expected for members of the Acinetobacter genus (Carr et al. 2003), whilst Ruegeria sp. was observed to be spherical in shape and readily formed chains (Fig. 2C,D). Pseudomonas sp. demonstrated a rod-shaped morphology (Fig. 2E,F). Pseudomonas colonies were hard and dry with a characteristic wrinkled appearance as expected for Pseudomonas stutzerii (Lalucat et al. 2006). The occurrence of irregular polygon-like structures or concentric zones was also noted, as has been described earlier for Pseudomonas stutzerii (van Niel \& Allen 1952, Lalucat et al. 2006).

\section{Growth experiments of axenic algal and bacterial cultures}

Total cell counts and dead cell counts of Tetraselmis indica in axenic and xenic cultures and in axenic cultures in combination with each isolated bacterium were studied for a period of algal growth (Figs. 3 to 5). Bacterial cell concentrations in the xenic culture gradually increased with time, reaching a concentration of $32.8 \times 10^{6}$ on the 28th day after inoculation. A rapid decline in total cell counts was recorded in the axenic compared to xenic cultures in the senescent phase of algal growth (Fig. 3). In the senescent phase, the total algal cell counts in the axenic culture with either Acinetobacter sp. or Ruegeria sp. were relatively high (Fig. 4) and the dead cell counts showed a significant reduction (Fig. 5). This was in contrast to axenic culture alone and axenic culture with Pseudomonas sp., which showed lower total cell counts (Fig. 4) and increased dead cell counts (Fig. 5). Significant cell lysis and hence a decrease in total cell counts was observed in axenic cultures during the senescent phase, whereas no such lysis was observed in xenic cultures. The presence of bacteria in xenic cultures led to an increased specific growth rate of $0.20 \mathrm{~d}^{-1}$ compared to axenic cultures with a specific growth rate of $0.15 \mathrm{~d}^{-1}$ in the exponential phase. The presence of bacteria on the discarded cell walls of alga in the xenic culture was observed using SYBR Gold staining and epifluorescence microscopy (Fig. 6).

\section{Carbohydrate utilisation (mono- and disaccharide)}

In the control tubes, to which bacteria were not added, the carbohydrate substrate was not utilised and there was no subsequent change in the colour of the indicator and no evolution of gas, indicating a negative reaction. Some bacterial strains possess enzymes that degrade peptones present in the media to amino acids. These in turn are enzymatically converted by oxidative deamination into keto amino acids before being metabolised through the Krebs cycle for energy production. These reactions release ammonia, which accumulates in the medium, forming ammonium hydroxide and producing an alkaline environment, causing the colour of the media to alter from red to pink. Pink media was observed in the control tubes with no carbohydrates for Pseudomonas sp. and Ruegeria sp., indicating that these 


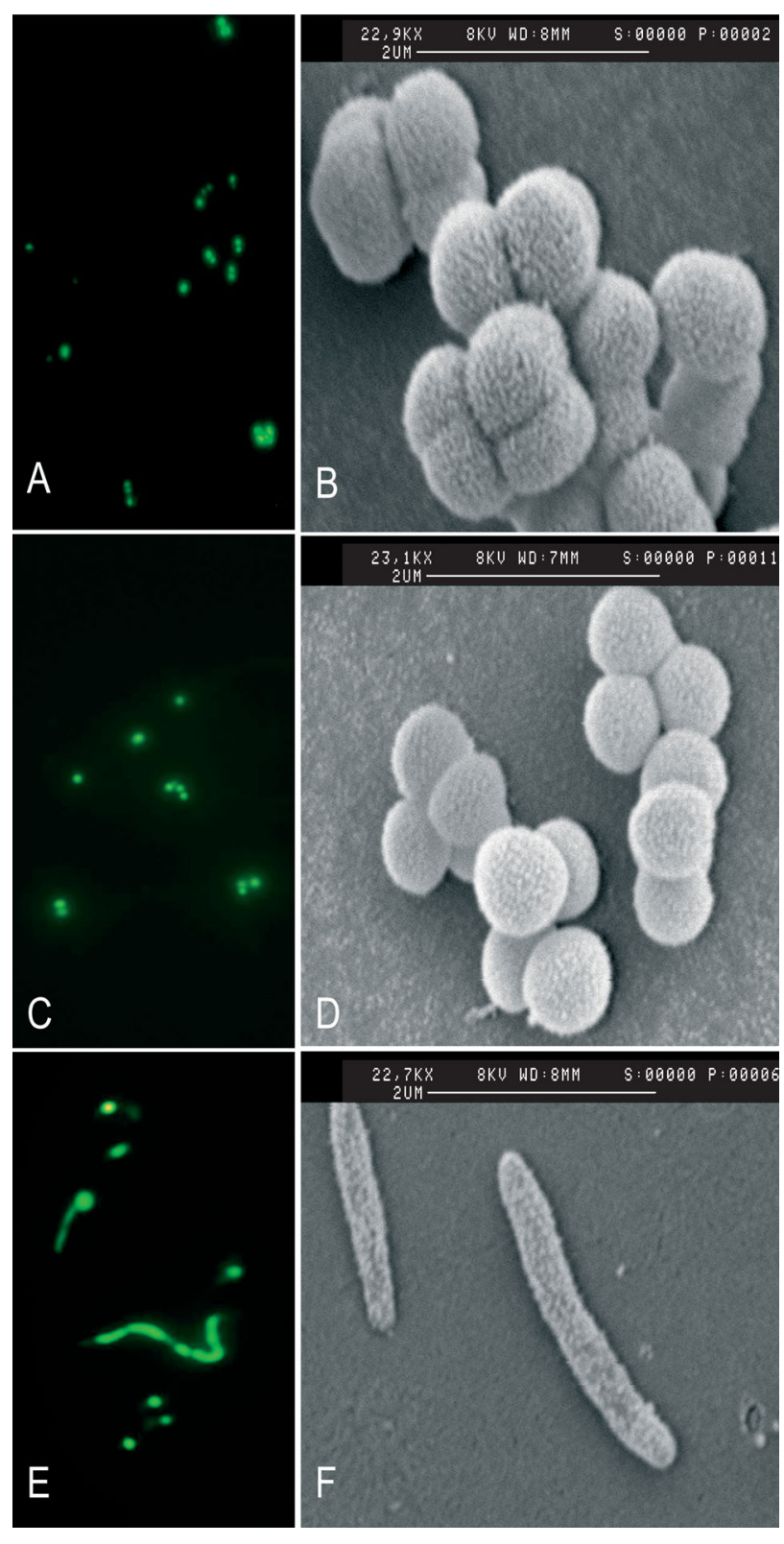

Fig. 2. Acinetobacter sp., Pseudomonas sp. and Ruegeria sp. Morphology of the isolated bacteria. (A,B) Epifluorescence and scanning electron microscopy (SEM) micrograph of Acinetobacter sp. showing bacteria present in pairs; $(\mathrm{C}, \mathrm{D})$ epifluorescence and SEM micrograph of Ruegeria sp. showing its spherical morphology; (E,F) epifluorescence and SEM micrograph of Pseudomonas sp. showing its rod-shaped morphology

enzymes were present. Acinetobacter sp. caused all the sugar solutions tested to turn yellow, indicating the formation of an acidic waste product following hydrolysation of the carbohydrate tested. The production of gas was observed only when sucrose was

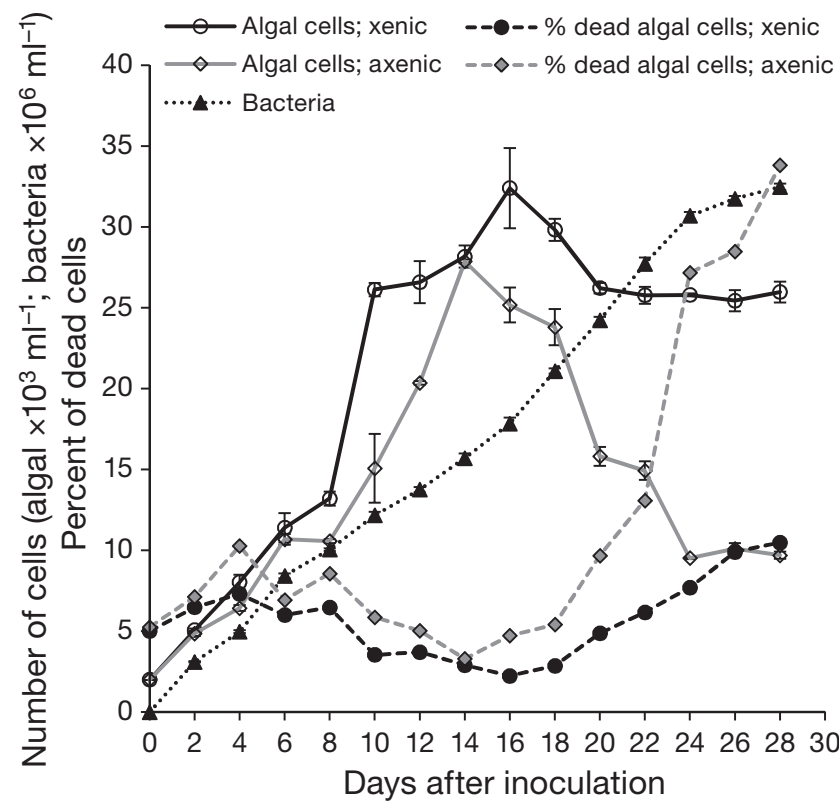

Fig. 3. Tetraselmis indica. Variation in total algal concentration, and percentage of dead algal cells in algal cultures without (axenic) and with (xenic) bacteria. Addition of a mixed community of bacteria (present in the original algal isolate) to the axenic algal cultures led to the increase in bacterial concentrations

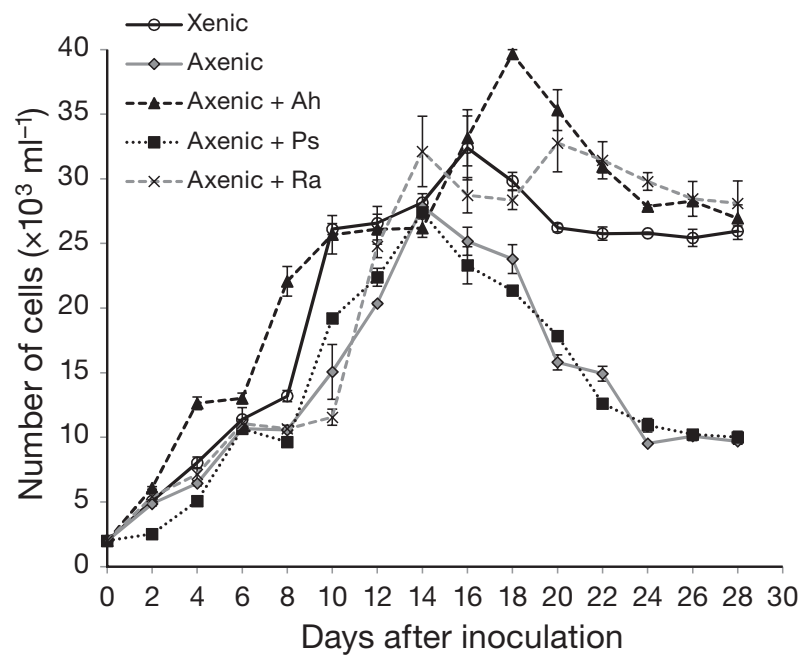

Fig. 4. Tetraselmis indica. Total algal cell concentrations in axenic and xenic cultures, and axenic cultures inoculated with each of the bacterial species isolated. Ps: Pseudomonas sp.; Ah: Acinetobacter sp.; Ra: Ruegeria sp. Values are means of triplicates $\pm \mathrm{SE}$

utilised as the carbohydrate source (Fig. 7). Pseudomonas sp. and Ruegeria sp. were unable to utilise some of the tested carbohydrates (Table 1) and no gas production was observed by either of these 2 bacterial strains with any of the substrates. 


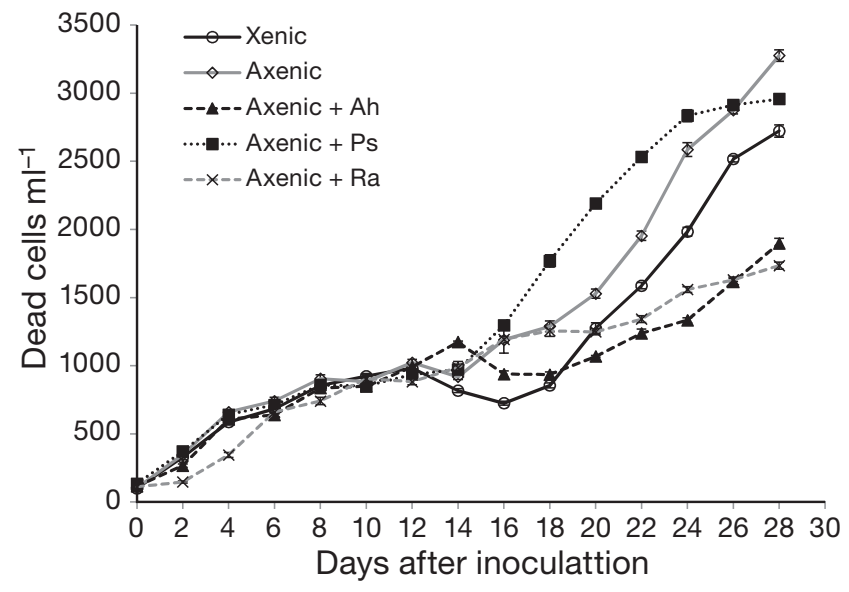

Fig. 5. Tetraselmis indica. Dead cell concentrations from the experiment described in Fig. 4 for axenic and xenic cultures, and axenic cultures inoculated with each of the bacterial species isolated. Ps: Pseudomonas sp.; Ah: Acinetobacter sp.;

Ra: Ruegeria sp. Values are means of triplicates $\pm \mathrm{SE}$

\section{Evaluation of the biodegradability of polysaccharides}

Pseudomonas sp. and Acinetobacter sp. showed carbohydrase activity and formed a halo-like precipitation zone (Fig. 8) with 4 (azo-galactan, azo-carob galactomannan, $\beta$-glucan and pectin) of the 8 carbohydrate substrates tested (Table 2), whereas Ruegeria sp. showed much less carbohydrase activity and only with pectin. Additionally, Pseudomonas sp. also demonstrated a low level of activity of the enzyme dextrinase.

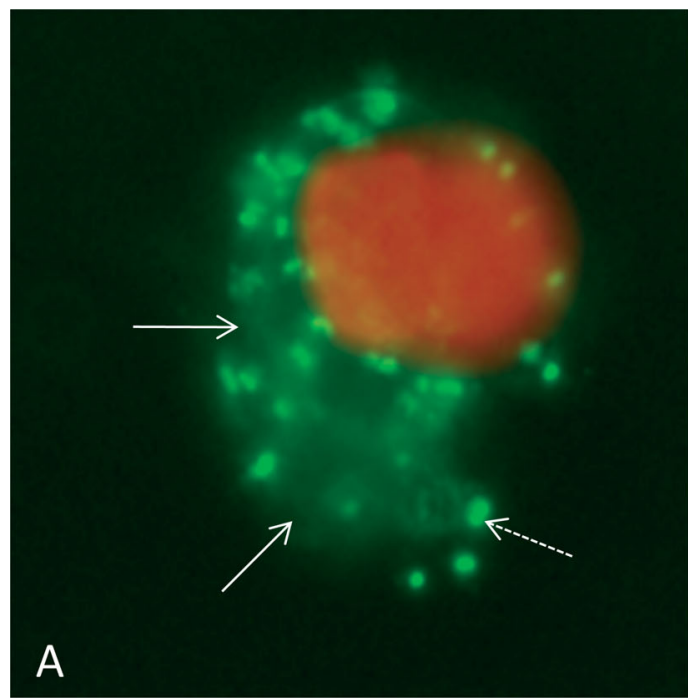

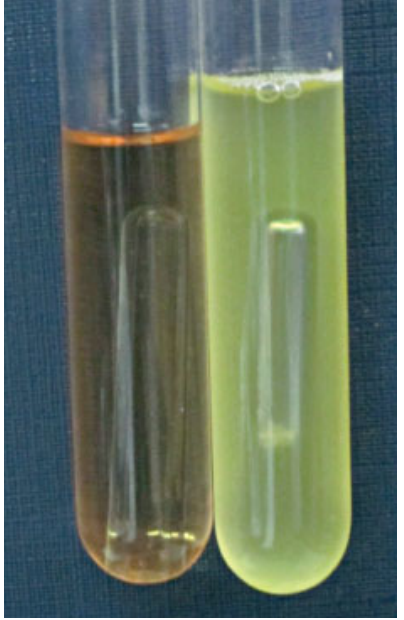

Fig. 7. Acinetobacter sp. Utilisation of sucrose by the isolated bacteria. The tube on the left is the control and the tube of the right demonstrates the colour change in the media following utilisation of the sucrose and the production of gas in the inverted tube

\section{DISCUSSION}

This study has investigated the influence of bacteria on the cell growth and cell death kinetics of Tetraselmis indica under culture conditions. The study showed that in contrast to xenic culture, reduced cell growth and enhanced mortality occurred in axenic culture. Bacterial inoculation into cultures of $T$. indica had a pronounced effect on algal growth, which either decreased (as observed with Pseudomonas sp.) or increased (as observed with Acinetobacter sp.). Following inoculation with Acinetobacter sp. and Ruegeria sp., prolonged survival was observed. Bacterially regenerated carbon from the discarded cell walls was very likely utilised by the

Fig. 6. Tetraselmis indica. (A) Epifluorescent micrograph showing the attachment of bacteria to the discarded cell wall of T. indica; solid arrows point towards the cell wall and the dotted arrow shows bacterial cells. (B) Phase contrast micrograph of the discarded and disintegrating cell wall showing the presence of bacteria; solid arrows point towards the disintegrating cell wall and bacteria and the dotted arrow shows a live algal cell 
Table 1. Acinetobacter sp., Pseudomonas sp. and Ruegeria sp. Utilisation of different carbohydrates by the 3 bacterial species isolated. + indicates the sugar was utilised and - that the bacteria were unable to utilise it

\begin{tabular}{lccc|}
\hline Sugar & Pseudomonas sp. & Acinetobacter sp. & Ruegeria sp. \\
\hline Sucrose & - & + (with production of gas $)$ & - \\
Dextrose & + & + & + \\
D-(+)-mannose & + & + & + \\
D-(+)-xylose & - & + & + \\
D-(+)-maltose & - & + & + \\
Lactose & - & + & - \\
D-(-)-mannitol & + & + & + \\
L-(+)-arabinose & + & + & + \\
D-(+)-galactose & + & + & + \\
N-acetyl glucosamine & - & + & + \\
D-glucuronic acid & - & + & + \\
\hline
\end{tabular}

cultures during the senescent phase, thereby prolonging the survival of the T. indica population. This reinforces the concept that bacteria can enhance the growth of algae.

Another interesting result was that the xenic culture, which contained both culturable and non-culturable bacteria, demonstrated less growth compared to that associated with $\mathrm{Aci}$ netobacter sp. alone. Therefore, there could be internal competition within the bacterial community that results in this reduced growth of the alga. In the xenic cultures, bacteria were found to be attached to the discarded
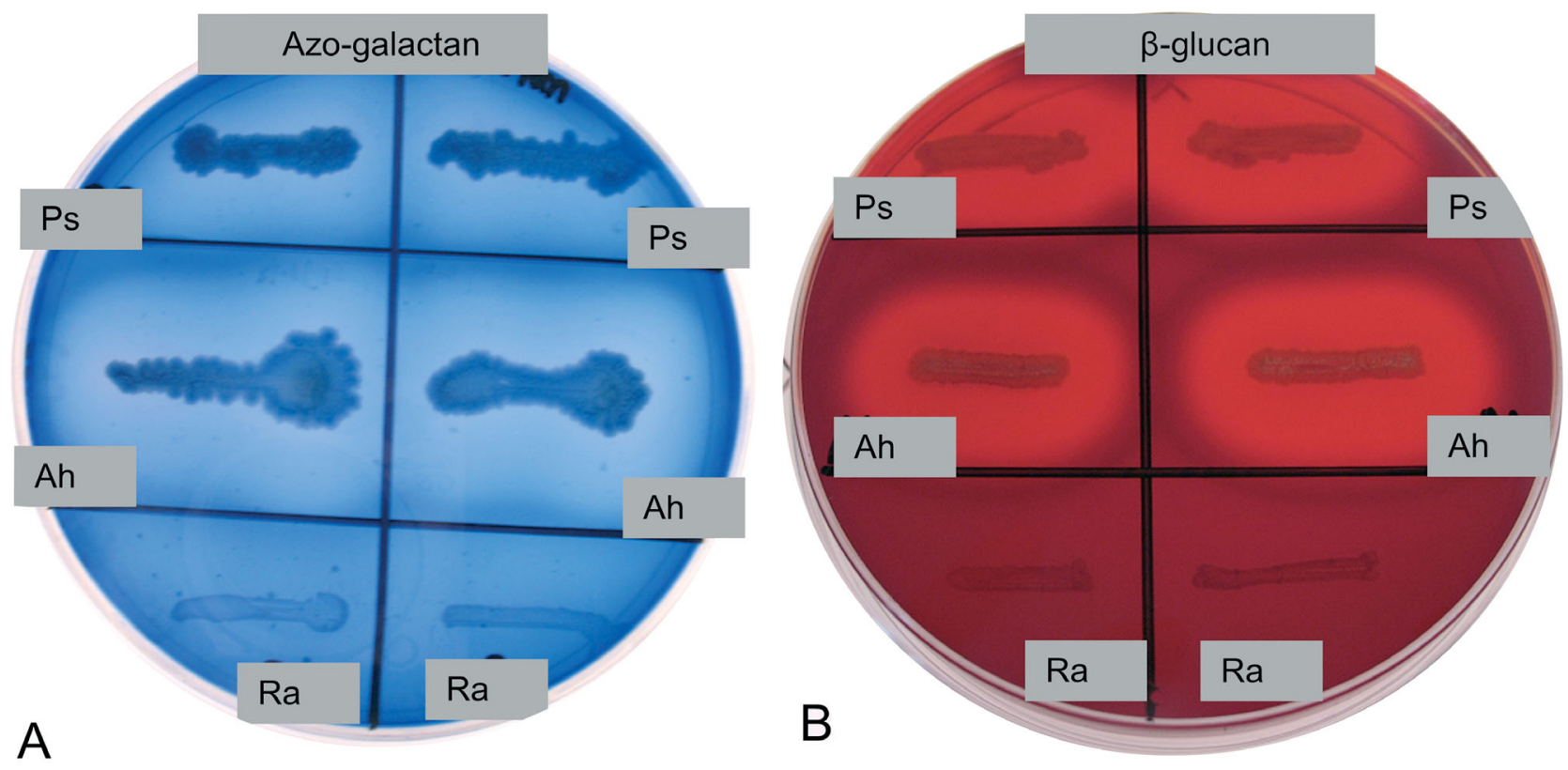

Fig. 8. Acinetobacter sp., Pseudomonas sp. and Ruegeria sp. Degradation of carbohydrates by the isolated bacteria. Ps: Pseudomonas sp., Ah: Acinetobacter sp., Ra: Ruegeria sp. (A) Activity of endo-1,4- $\beta$-galactanase when azo-galactan was the substrate,

(B) activity of $\beta$-glucanase when $\beta$-glucan was the substrate

Table 2. Acinetobacter sp., Pseudomonas sp. and Ruegeria sp. Carbohydrate substrate utilisation by the 3 bacterial species isolated. - indicates no degradation of the substrate whilst + indicates degradation of the substrate

\begin{tabular}{|c|c|c|c|}
\hline Carbohydrate (enzyme activity) & Pseudomonas sp. & Acinetobacter sp. & Ruegeria sp. \\
\hline Azo-galactan (endo-1,4- $\beta$-galactanase) & + & + & - \\
\hline Azo-carob galactomannan ( $\beta$-mannanase) & + & + & - \\
\hline$\beta$-glucan ( $\beta$-glucanase) & + & + & - \\
\hline Red pullulan (dextrinase) & + & - & - \\
\hline Azo-CM-cellulose (cellulase) & - & - & - \\
\hline Wheat arabinoxylan & - & - & - \\
\hline Citrus pectin (pectinase) & + & + & + \\
\hline AZ-rhamnogalacturonan (rhamnogalacturonanase) & - & - & - \\
\hline
\end{tabular}


cell walls (Fig. 6 and see the animation in Supplement 2 at www.int-res.com/articles/suppl/b015p061_ supp/). The cell wall of Tetraselmis has been shown to be made of a pectin-like material, with galactose and galacturonic acid as major components (Lewin 1958, Gooday 1971). Pectins can consist of either a polymer of unsubstituted polygalacturonic acid residues or a backbone of galacturonic acid and rhamnose residues that are attached to galactan and arabinan side chains. Galacturonic acid and some other 2-keto sugar acids impart an acidic character to the cell walls of Tetraselmis (Becker et al. 1991, 1998). Experimental results of the current study on the bacterial utilisation of different carbohydrate substrates indicated which carbohydrate substrates these bacteria depend on for their survival. Bacterial strains were found to produce carbohydrases for degradation of polysaccharides generally present in the cell wall of Tetraselmis (glucans, galactans, galactomannans and pectins), whereas no such utilisation was observed for other wall substrates, such as cellulose, arabinoxylan and rhamnogalacturonan. The production of carbohydrases such as pectinases, glucanases, galactanases and mannanases from various species of Pseudomonas and Acinetobacter has also been reported in earlier studies (Katohda et al. 1979, Simonson et al. 1982, Braithwaite et al. 1995, 1997, Titapoka et al. 2008, Aboaba 2009, Zheng et al. 2011). Since Acinetobacter sp. and Pseudomonas sp. were able to utilise the same substrates at almost equal levels, as indicated by the carbohydrate utilisation results, this suggests that they may compete for the same substrates within the cell wall of $T$. indica. Importantly, when the alga was grown with only Pseudomonas sp. present, its growth was inhibited, leading to a prolonged lag phase. Growth resumed only when the algal culture was in its exponential phase, and became arrested again when the senescent phase was reached. Therefore, it can be speculated that Pseudomonas sp. has a negative influence on algal growth, notably it could be toxic for cell culture, and this bacterium is able to survive only as a competitor with the other associated bacteria in the cell wall environment. Even though Ruegeria sp. enhanced the survival of the alga after the senescent phase, there was a neutral effect on the culture growth during the lag phase. Hence, it can be concluded from this study that each bacterium associated with $T$. indica demonstrates a differential influence on algal growth.

As demonstrated in this study, these algae-associated bacteria are a potential source of useful carbohydrases and could be used to prevent the forma- tion of biofilms and in applications involving biofilm dispersal due to their polysaccharide-degrading capabilities (Kaplan et al. 2003, Ramasubbu et al. 2005). In addition, Acinetobacter sp. could also be used in microalgal aquaculture to increase growth of algae. More widely, this study reinforces the ecological importance of bacteria in marine biogeochemical cycles, in hydrolysing organic matter and in influencing the dynamics of phytoplankton.

Acknowledgements. This document is an output from the UKIERI (UK-INDIA Education and Research Initiative) project entitled 'Development of Methodology for Biological Assessment of Ballast Water Management Systems' funded by the British Council, the UK Department for Education and Skills (DfES), Office of Science and Innovation, the FCO, Scotland, Northern Ireland, Wales, GSK, BP, Shell and BAE for the benefit of the India Higher Education Sector and the UK Higher Education Sector. The views expressed are not necessarily those of the funding bodies. The authors wish to thank our colleagues at National Institute of Oceanography (NIO) and Newcastle University for their help and support, especially S. Naik for her help in the carbohydrate utilisation studies. This work was supported by the Council of Scientific and Industrial Research (CSIR), India and the British Council, UK. This is NIO contribution no. 5134.

\section{LITERATURE CITED}

Aboaba S (2009) The role of pectinase enzyme in the development of soft rot caused by Pseudomonas fluorescens in the purple variety of onions (Allium cepa). Afr J Microbiol Res 3:163-167

Altschul SF, Gish W, Miller W, Myers EW, Lipman DJ (1990) Basic local alignment search tool. J Mol Biol 215:403-410

- Aota Y, Nakajima H (2001) Mutualistic relationships between phytoplankton and bacteria caused by carbon excretion from phytoplankton. Ecol Res 16:289-299

> Becker B, Becker D, Kamerling JP, Melkonian M (1991) 2-keto sugar acids in green flagellates: a chemical marker for prasinophycean scales. J Phycol 27:498-504

- Becker B, Melkonian M, Kamerling JP (1998) The cell wall (theca) of Tetraselmis striata: macromolecular composition and structural elements of the complex polysaccharides. J Phycol 34:779-787

Bell WH, Mitchell R (1972) Chemotactic and growth responses of marine bacteria to algal extracellular products. Biol Bull 143:265-277

Bell WH, Sakshaug E (1980) Bacterial utilization of algal products. 2: a kinetic study of natural populations. Limnol Oceanogr 25:1021-1033

Bershova OI, Kopteva ZP, Tantsyurenko EV (1968) The interrelations between blue-green algae-the causative agents of 'water blooms' and bacteria. In: Topachevsky AV (ed) Tsventenie Vody. Naukova Dunka, Kiev, p 159-171

Birnboim HC, Doly J (1979) A rapid alkaline extraction procedure for screening recombinant plasmid DNA. Nucleic Acids Res 7:1513-1523

Bjørnsen PK (1988) Phytoplankton exudation of organic matter: Why do healthy cells do it? Limnol Oceanogr 33: $151-154$ 
Braithwaite KL, Black GW, Hazlewood GP, Ali BRS, Gilbert HJ (1995) A non-modular endo- $\beta$-1,4-mannanase from Pseudomonas fluorescens subspecies cellulosa. Biochem J 305:1005-1010

Braithwaite KL, Barna T, Spurway TD, Charnock SJ and others (1997) Evidence that galactanase A from Pseudomonas fluorescens subspecies cellulosa is a retaining family 53 glycosyl hydrolase in which E161 and E270 are the catalytic residues. Biochemistry 36:15489-15500

> Brussaard CPD, Riegman R (1998) Influence of bacteria on phytoplankton cell mortality with phosphorus or nitrogen as the algal-growth-limiting nutrient. Aquat Microb Ecol 14:271-280

Caldwell DE (1977) The planktonic microflora of lakes. CRC Crit Rev Microbiol 5:305-370

Carr EL, Kämpfer P, Patel BKC, Gürtler V, Seviour RJ (2003) Seven novel species of Acinetobacter isolated from activated sludge. Int J Syst Evol Microbiol 53:953-963

Cid A, Abalde J, Herrero C (1992) High yield mixotrophic cultures of the marine microalga Tetraselmis suecica (Kilin) Butch (Prasinophyceae). J Appl Phycol 4:31-37 Cole JJ (1982) Interactions between bacteria and algae in aquatic ecosystems. Annu Rev Ecol Syst 13:291-314

Cole JJ, Findlay S, Pace M (1988) Bacterial production in fresh and saltwater ecosystems: a cross-system overview. Mar Ecol Prog Ser 43:1-10

> Coveney MF (1982) Bacterial uptake of photosynthetic carbon from freshwater phytoplankton. Oikos 38:8-20

Coveney MF, Wetzel RG (1989) Bacterial metabolism of algal extracellular carbon. Hydrobiologia 173:141-149

de Kluijver A, Soetaert K, Schulz KG, Riebesell U, Bellerby RGJ, Middelburg JJ (2010) Phytoplankton-bacteria coupling under elevated $\mathrm{CO}_{2}$ levels: a stable isotope labelling study. Biogeosciences 7:3783-3797

del Giorgio PA, Cole JJ, Cimbleris A (1997) Respiration rates in bacteria exceed phytoplankton production in unproductive aquatic systems. Nature 385:148-151

Ducklow HW, Carlson CA (1992) Oceanic bacterial productivity. Adv Microb Ecol 12:113-181

> Gooday GW (1971) A biochemical and autoradiographic study of the role of the Golgi bodies in thecal formation in Platymonas tetrathele. J Exp Bot 22:959-971

Guillard RRL, Ryther JH (1962) Studies of marine planktonic diatoms. I. Cyclotella nana Hustedt and Detonula confervacea Cleve. Can J Microbiol 8:229-239

Hall TA (1999) BioEdit: a user-friendly biological sequence alignment editor and analysis program for Windows 95/98/NT. Nucleic Acids Symp Ser 41:95-98

Hobbie JE, Daley RJ, Jasper S (1977) Use of nuclepore filters for counting bacteria by fluorescence microscopy. Appl Environ Microbiol 33:1225-1228

Huang XP, Zhu XB, Liu JG, Wang XT, Xu WH, Kang XL (2004) Study on enrichment of N, P and purification of water quality by several species of algae. Mark Sci 28: 39-42

> Kaplan JB, Ragunath C, Ramasubbu N, Fine DH (2003) Detachment of Actinobacillus actinomycetemcomitans biofilm cells by an endogenous beta-hexosaminidase activity. J Bacteriol 185:4693-4698

Katohda S, Suzuki F, Katsuki S, Sato T (1979) Purification and some properties of endo- $\beta$-1,6-glucanase from Acinetobacter sp. Agric Biol Chem 43:2029-2034

Kogure K, Simidu U, Taga N (1981) Bacterial attachment to phytoplankton in seawater. J Exp Mar Biol Ecol 56: 197-204
Kormas KA (2005) Bacterioplankton growth on extracellular organic carbon from marine microalgal cultures. Cah Biol Mar 46:241-251

$>$ Kuentzel LE (1969) Bacteria, carbon dioxide and algal blooms. J Water Pollut Control Fed 41:1737-1747

Lalucat J, Bennasar A, Bosch R, García-Valdés E, Palleroni NJ (2006) Biology of Pseudomonas stutzeri. Microbiol Mol Biol Rev 70:510-547

Lane DJ (1991) 16S/23S rRNA sequencing. In: Stackebrandt E, Goodfellow M (eds) Nucleic acid techniques in bacterial systematics. John Wiley \& Sons, New York, NY, p 115-175

Lange W (1967) Effects of carbohydrates on the symbiotic growth of the planktonic blue-green algae with bacteria. Nature 215:1277-1278

Lange W (1970) Cyanophyta-bacteria systems: effects of added carbon compounds or phosphate on algal growth at low nutrient concentrations. J Phycol 6:230-234

Lange W (1971) Enhancement of algal growth in cyanobacteria systems by carbonaceous compounds. Can J Microbiol 17:303-314

Larkin MA, Blackshields G, Brown NP, Chenna R and others (2007) ClustalW and ClustalX version 2.0. Bioinformatics 23:2947-2948

Levasseur M, Thompson PA, Harrison PJ (1993) Physiological acclimation of marine phytoplankton to different nitrogen sources. J Phycol 29:587-595

> Lewin RA (1958) The cell walls of Platymonas. J Gen Microbiol 19:87-90

> Mague TH, Friberg E, Hughes DJ, Morris I (1980) Extracellular release of carbon by marine phytoplankton: a physiological approach. Limnol Oceanogr 25:262-279

> Maurin N, Amblard C, Bourdier G (1997) Phytoplanktonic excretion and bacterial reassimilation in an oligomesotrophic lake: molecular weight fractionation. J Plankton Res 19:1045-1068

Meffert ME, Overbeck J (1985) Dynamics of chlorophyll and photosynthesis in natural phytoplankton associations. II. Primary productivity, quantum yields and photosynthetic rates in small north German lakes. Arch Hydrobiol 104: 363-385

> Moreno F, Laine L (2004) The flow cytometry, a new tool for trophic coastal ecosystem diagnostic. Ecol Indic 4:161-176

Myklestad S, Holm-Hansen O, Varum KM, Volcam BE (1989) Rate of release of extracellular amino acids and carbohydrates from the marine diatom Chaetoceros affinis. J Plankton Res 11:763-773

> Obernosterer I, Herndl GJ (1995) Phytoplankton extracellular release and bacterial growth: dependence on inorganic N:P ratio. Mar Ecol Prog Ser 116:247-257

> Paerl HW, Pinckney JL (1996) A mini-review of microbial consortia: their roles in aquatic production and biogeochemical cycling. Microb Ecol 31:225-247

Ramasubbu N, Thomas LM, Ragunath C, Kaplan JB (2005) Structural analysis of dispersin B, a biofilm-releasing glycoside hydrolase from the periodontopathogen Actinobacillus actinomycetemcomitans. J Mol Biol 349:475-486

Simidu U, Ashino K, Kaneko E (1971) Bacterial flora of phyto- and zooplankton in the inshore water of Japan. Can J Microbiol 17:1157-1160

Simonson LG, Gaugler RW, Lamberts BL, Reiher DA (1982) Purification and properties of endo-1,3-alpha-D-glucanase from Pseudomonas. Biochim Biophys Acta 715: 189-195

Tamura K, Nei M (1993) Estimation of the number of 
nucleotide substitutions in the control region of mitochondrial DNA in humans and chimpanzees. Mol Biol Evol 10:512-526

Tamura K, Peterson D, Peterson N, Stecher G, Nei M, Kumar S (2011) MEGA5: Molecular evolutionary genetics analysis using maximum likelihood, evolutionary distance, and maximum parsimony methods. Mol Biol Evol

Titapoka S, Keawsompong S, Haltrich D, Nitisinprasert S (2008) Selection and characterization of mannanaseproducing bacteria useful for the formation of prebiotic manno-oligosaccharides from copra meal. World J Microbiol Biotechnol 24:1425-1433

Editorial responsibility: Kedong Yin,

Nathan, Australia van Niel CB, Allen MB (1952) A note on Pseudomonas stutzeri. J Bacteriol 64:413-422

Williams PJleB (1981) Incorporation of microheterotrophic processes into the classical paradigm of the plankton food web. Kieler Meeresforsch 51:1-28

Zheng L, Du B, Xue W (2011) Screening and identification of Acinetobacter junii for Apocynum vernetum L. fiber enzymatic retting. J Text Inst 102:675-680

Zifeng W, Tian X, Shaojun P, Min L, Haidong Y (2009) Isolation and identification of bacteria associated with the surfaces of several algal species. Chin J Oceanology Limnol $27: 487-492$

Submitted: May 13, 2011; Accepted: December 14, 2011 Proofs received from author(s): February 28, 2012 